\title{
THE INFLUENCE OF CUSTOMER-CENTRIC STRATEGY TOWARD TOURIST SATISFACTION
}

\author{
Agustinawati ${ }^{1}$, Samsidar ${ }^{2}$, Halida Bahri ${ }^{3}$, Juliana ${ }^{4}$, Pendi ${ }^{5}$ \\ $1,2,3,4,5$ \\ Faculty of Economics and Business, Universitas Malikussaleh
}

E-mail: ${ }^{1}$ agustinawati@unimal.ac.id, ${ }^{2}$ samsidar@unimal.ac.id, ${ }^{3}$ halidabahri@unimal.ac.id, 4juliana@mhs.unimal.ac.id, 5 pendi@mhs.unimal.ac.id

\begin{abstract}
This study aims to investigate the infleunce of customer centric marketing mix on satisfaction for tourists in context of Aceh. The Halal tourism destination such as Ujong Blang beach, Seumadu beach, Lancok beach, Pangah Beach, Waduk Jeulikat, Lhok Seulayang, Museum Geudong and Gunung Sala is the latest destination in North Aceh and Lhokseumawe, Indonesia. This destination currently very in great demand by the tourists. A survey questionnaire is used to conduct this study. A sample of 200 tourists participated in the study. The findings reveal the significant positive relationship of three marketing mix elements with tourists' satisfaction for tourism services in the context of Aceh.
\end{abstract}

Keywords: customer centric, tourist satisfaction, halal tourism

\section{INTRODUCTION}

The tourism sector is determined as one of the leading development sectors in Indonesia. The growth of halal tourism in Indonesia is a new trend in the tourism service industry with the establishment of 3 halal tourism destinations, one of which is Aceh, which has been awarded the fourth rank of the Top 10 Halal Friendly Holiday Destinations in 2016 with the success of Aceh Province winning two awards namely the category of World's Best Airport for Halal Travelers: and World's Best Halal Cultural Destination. [1][2].

Indonesia has great potential and opportunities in developing the halal tourism industry. The North Aceh and Lhokseumawe is one of the districts in the province of Aceh Indonesia. There are many halal tourism destinations that have been known by domestic and foreign tourists. The Halal tourism destination such as Ujong Blang Beach, Seumadu Baeach, Waduk Jeulikat, Lancok Beach, Lhok Seulayang, Pangah Beach, Museum Geudong and Gunung Sala is the latest destination currently very in great demand by the tourists.[3]. Halal tourism is any activity, event and experience carried out in a state of travel that complies with Islamic standards. Halal tourism, not only to travel to places that have religious value, but this concept is more to the implementation that prioritizes halal standards

services for Muslims, such as providing halal food or culinary, places of worship, not preparing entertainment that is not in accordance with Islamic sharia. the concept of halal tourism is more focused on tourism that is full of Islamic values by providing halal products and in accordance with sharia, not only for the consumption of Muslim tourists, but also for non-Muslim tourists. [4][5].

In marketing activities, the important thing to note is how a service provider pays attention to the marketing mix of services which can then measure tourist satisfaction.[6][7]. The service 4C's marketing mix is used to classify every part of a tourism destination such customer solution, customer cost, communication and convenience, so that measurement of tourist satisfaction is easier to do. In addition, the use of the marketing mix of services is used in the tourism industry, the company does not offer pure services to customers, but physical facilities and other offerings such as environmental 
conditions around tourist attractions, parking lots, design tourist attractions, and others.[8][9]. The four main points in the 4C's marketing mix of services consisting of customer solution, customer cost, communication and convenience to be used to interpret the experiences felt by tourists at a tourist site to determine the level of satisfaction or dissatisfaction of tourists through existing variables[10].[11]. The present study aims to find the Influence of Customer-Centric Strategy Toward Tourist Satisfaction in context of Aceh.

\section{Literature review}

\subsection{Tourism and Tourists}

Tourism is as a change in the temporary residence of someone outside of their residence for a reason and not to do activities that generate wages [10][12][13] tourism is all activities in society related to tourists, while tourists are people who travel from their homes without settling in the

$$
\text { places they visit.[14][15][16]. }
$$

\subsection{Halal Tourism}

Halal tourism is one of the tourism systems intended for Muslim tourists whose implementation complies with Islamic rules. Every activity, event and experience carried out in a tourism destination must be in accordance with Islamic sharia [4][3][17] The trend of halal tourism is becoming a modern lifestyle in meeting the needs of making a tour which is a strength of the highly developed global tourism industry. Halal tourism promotes halal products and is safe for consumption by Muslim tourists. For non-Muslims, Islamic tourism with halal products is a healthy guarantee.Sharia tourism is not interpreted as such, but tourism where it originates from nature, culture, or artificial is framed by the values of Islamic[18] [19][3][1][2][4].

\subsection{Marketing Mix}

Marketing mix is one of the tools in the field of marketing that can be used to develop a tourism industry. service marketing is an action offered by the producer to the consumer, in the sense that the services rendered cannot be seen, felt, heard or touched before being consumed. The service marketing mix is a development of the marketing mix. The marketing mix in the field of products includes 4P, namely: Product, Price, Place, and Promotion. In the service sector, experts add three other elements, namely People, Process, and Customer Service[7][11][20]. With market competition shifting from the product-oriented focus to a customer-oriented paradigm, some defects of the 4 P's Framework emerge. In the tourism industry, marketing mix is used to satisfy consumers by focusing on the quality of attractions. Product: Product is anything that is tangible and intangible that can meet the needs of consumer demand to be satisfied [6][24] tourism products are the overall services obtained, felt and enjoyed by tourists since he left the area and headed to the tourist destination and return to the place of origin [21][9]. Price: Price is a very important measure used by consumers to buy or not buy to meet the needs of goods and services. The price is the only element of the marketing mix that provides income for the organization.[23] [14][25][6]. Promotion: The company introduces its products and services to the market through promotional strategies. Goods and services produced by companies must be known, needed and requested by consumers, so companies must promote their products through advertising and promotion[26][24] promotion is "an activity to inform the benefits of the product and persuade customers to buy it[22][19]. Place: Place can provide time and distances as well. It also offers some novel ideas for travelling ways and declares some possible customers for tourism service. A prior research also explains about some marketing channels and put marketing 
mix with best distribution of services for many travel agencies[13][16] Places that are attractive to consumers are the most strategic, fun, and efficient places.

The 4C's developed by R. Lauterborn are the customer decision points corresponding to the marketer tools. They are customer solution, customer cost, communication and convenience. Customer Solution: Customers look forward to solve their problems. Incidentally the solution is the product. In tourist the problem can be hot to best utilize the vacation, or how to have a break from the monotony in life. Customer Cost: May far exceed the price of the product. A tourists destination may focus on the economy of the expenses at the destination.Communication: Each destination undertakes an effort to promote itself in the most impressive manner. However, how it gets communicated is most important. A great web site, along with lovely advertisements can all go waste with the media report of harassment or exploitation of tourist or even the spread of some health threats some hundreds of miles away from the destination. Convenience :Even if there are multiple logistics options for tourists they will always weigh them as per their convenience. Convenience can again have multiple dimension. It can be convenience in terms of logistics, language, culture and travel

\section{IMPLEMENTATION METHOD}

The data used in this study was collected from the results of a survey conducted by distributing questionnaires in the halal tourism destinations of the Ujong Blang Beach, Seumadu Baeach, Waduk Jeulikat, Lancok Beach, Lhok Seulayang, Pangah Beach, Museum Geudong and Gunung Sala in Aceh Indonesia. Data used in this research was distributed to the tourist located in aceh to collect the relevant data. This survey was conducted in July 2021, The respondents are randomly selected. The sample size for the present research is 200 tourist visiting halal tourism destination[32][33] The observed variables of $4 \mathrm{C}^{\prime} \mathrm{s}$ marketing mix including in the study were customer solution, customer cost, communication and convenience, to comprehend their impacts towards the tourist satisfaction. The correlation between variables is drawn in Figure 1.

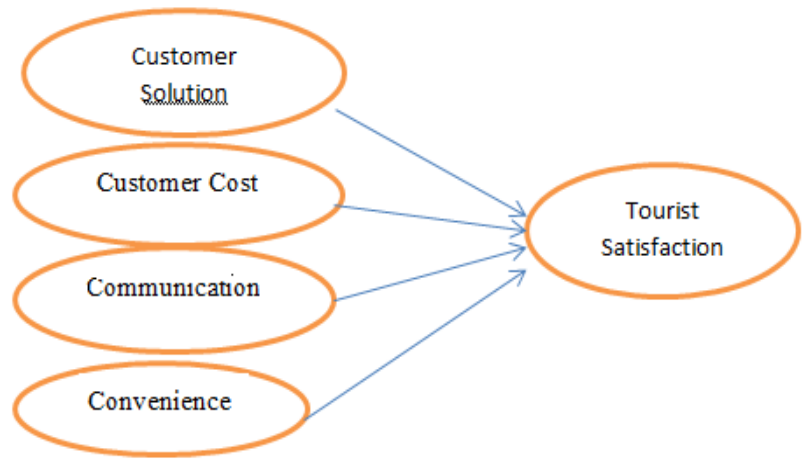

Fig. 1 Research model of correlation between 4C's marketing mix towards tourist satisfaction

The items of $4 \mathrm{C}^{\prime}$ 's marketing mix were measured on 5 point likert scale ranging from $1=$ strongly disagree to $5=$ strongly agree for assessing the marketing mix variable that affect the tourist satisfaction in halal tourism destination. Frequency and percentage were used to examine the demographic profile of the respondents. In addition, regression analysis was used to approximate the variation in satisfaction[34][35]. The model applied in this study as follows: 


$$
S=\alpha+\beta_{1} X_{1}+\beta_{2} X_{2}+\beta_{3} X_{3}+\beta_{4} X_{4}+e
$$

In addition, the hypotheses are:

$\mathrm{H}_{1}$ : Customer Solution and Tourist Satisfaction are positively related to each other.

$\mathrm{H}_{2}$ : Customer Cost and Tourist Satisfaction are positively related to each other.

$\mathrm{H}_{3}$ : Communication and Tourist Satisfaction are positively related to each other.

$\mathrm{H}_{4}$ : Convenience and Tourist Satisfaction are positively related to each other.

\section{Results and Discussion}

\subsection{Respondents profile}

The subjects were categorized into four groups: first-time visitors (12 / 6\%), 2-3 time $(71 / 35.5 \%), 4-5$ time $(34 / 17.0 \%)$ and $>5$ time $(83 / 81.5 \%)$. There were 118 (59\%) female respondents and $82(41 \%)$ male respondents. The respondents represented various age groups but the majority (35\%) were aged between 18 to 25 years old. About $(64.5 \%)$ of the respondents were married, while single made up $35.5 \%$ of the sample. One hundred and nine-four $(97 \%)$ respondents had reason to recreation/ interes halal tourism. From these data, the researcher concluded that more than $95 \%$ of the respondents intersted to travel and have vacations at halal tourism destinations. (Refer to Table 1).

Table 1. Respondents profile ( $\mathrm{N}=200$ )

\begin{tabular}{lcc}
\hline & Frequency & Percentage \\
\hline Man & 82 & $41 \%$ \\
Women & 118 & $59 \%$ \\
Maried & 129 & $64.5 \%$ \\
Not yet Maried & 71 & $35.5 \%$ \\
$18-25$ yrs & 70 & $35 \%$ \\
$26-35$ yrs & 64 & $32 \%$ \\
$36-45$ yrs & 51 & $25.5 \%$ \\
$>46$ yrs & 15 & $7.5 \%$ \\
Recreation/ interes halal tourism & 194 & $97 \%$ \\
Work & 6 & $3 \%$ \\
First time & 12 & $6 \%$ \\
$2-3$ time & 71 & $35.5 \%$ \\
$4-5$ time & 34 & $17.0 \%$ \\
& 83 & $41.5 \%$ \\
\hline
\end{tabular}

\subsection{Reliability}

Internal reliability of the questionnaire was tested by using Cronbach"s alpha. According to Ghozali, 2005, Cronbach's $\alpha$ with larger $\alpha$ values (greater than 0.60) indicates higher internal consistency in the measured dimension and hence greater reliability. In this study the entire variables Cronbach's alpha is greater than 0.60 (Table-2). So, it is clear that the questionnaire used in this study had strong internal reliability and it could be used with confidence for the application of next statistical analysis. (Refer to Table 2).

Table 2. Reliability Test 


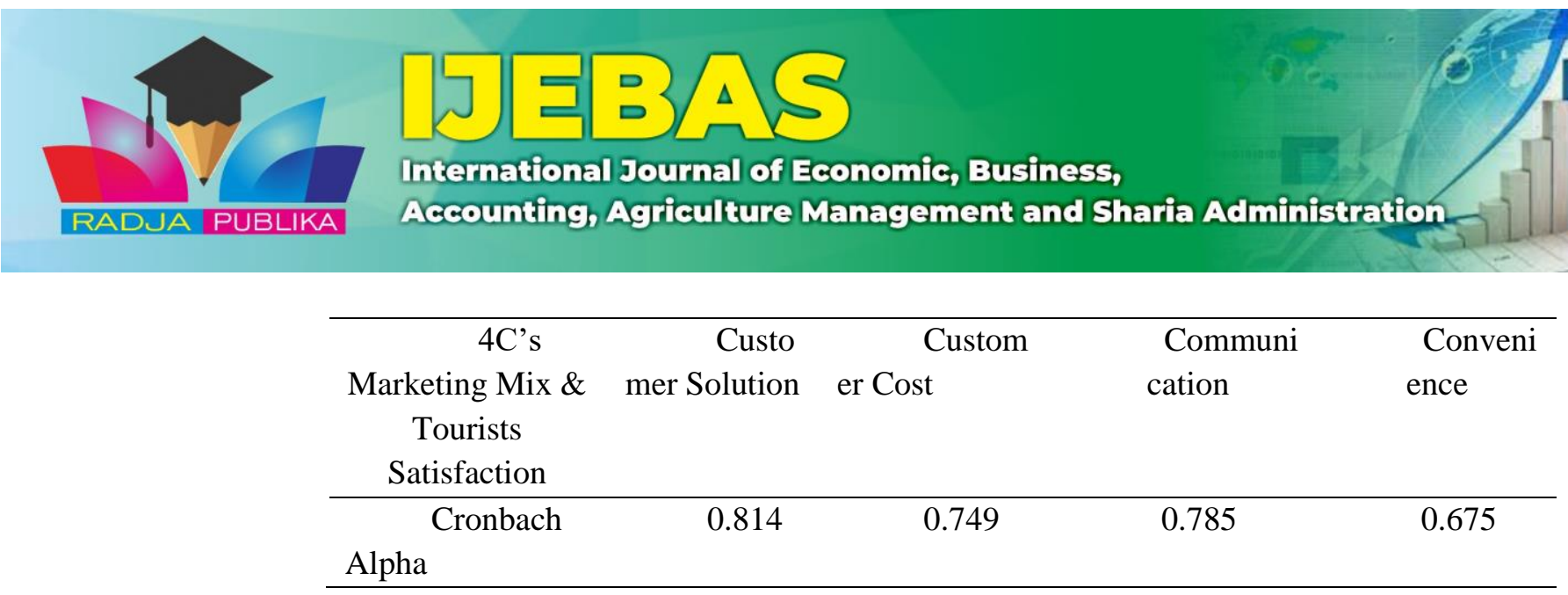

\subsection{Analysis}

Based on the linear regression equation, the three service marketing mix variables namely customer solution, customer cost and convenience have a positive regression coefficient. This means that an increase of the three marketing elements will increase tourist satisfaction with halal tourism destinations. Meanwhile, communication elements with negative coefficients will cause a decrease in the level of tourist satisfaction. this shows that the communication is not effective in increasing the number of tourists visiting. However, Simultaneously, the four elements of the service marketing mix significantly influence tourist satisfaction on halal tourism destinations in Aceh. The multiple regression equations for each variable can be written as follows:

$$
\mathrm{Y}=3.984+0.122 X_{1}+0.104 X_{2}-0.014 X_{3}+0.015 X_{4}
$$

To check the impact of halal tourism marketing mix as independent variables to tourist satisfation as dependent variable and linear regression analysis was applied to test the hypothesis developed. Results of linear regression analysis are shown in Table 3. The results of data analysis shows that hypothesis 1 is supported. The regression analysis shows a positive relationship between customer solution and tourist satisfaction. The customer solution has a significant effect with a value of 0.015 and a positive regression coefficient of 0.122 . This shows that the customer solution has an effect on tourist satisfaction with halal tourism destinations in Aceh. Hypothesis 2 of the study is also supported by the results as the results show a positive relationship between customer cost and tourist satisfaction. The customer cost has a significant effect with a value of 0.048 and a positive regression coefficient of 0.104 . The regression output of Hypothesis 3 not supports the hypothesis presented by the study suggesting a negative relationship between communication and tourist satisfaction. The communication not have a significant effect with a value of 0.741 and a negative regression coefficient of -0.104 . This shows that the communication not have an effect on tourist satisfaction with halal tourism destinations in Aceh. Hypothesis 4 of the study is not supported by the results as the results show a positive relationship between convenience and tourist satisfaction. The convenience not have a significant effect with a value of 0.800 and a positive regression coefficient of 0.015 .

Table 3. Regression Analysis

\begin{tabular}{|c|c|c|c|c|c|c|c|}
\hline \multirow[t]{2}{*}{$X$} & \multirow[t]{2}{*}{ B } & \multicolumn{2}{|c|}{$\mathrm{S}$} & \multirow[t]{2}{*}{ ] } & \multirow{2}{*}{ ig. } & \multirow{2}{*}{$\begin{array}{r}\mathrm{T} \\
\text { olerance }\end{array}$} & \multirow[b]{2}{*}{ IF } \\
\hline & & $\begin{array}{l}\text { td. } \\
\text { Error }\end{array}$ & eta & & & & \\
\hline (Constant) & 3 & & & & $\vdots$ & & \\
\hline & .984 & .028 & & .874 & 000 & & \\
\hline customer & 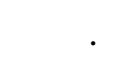 & & & . & c & .5 & \\
\hline $\begin{array}{l}\text { solution } \\
\text { customer }\end{array}$ & 122 & 050 & 182 & .450 & 015 & $\begin{array}{r}09 \\
.5\end{array}$ & .966 \\
\hline $\operatorname{cost}$ & 104 & 052 & 144 & .993 & 048 & 41 & .849 \\
\hline
\end{tabular}


Volume 1 No 2 (2021)

The Influence Of Customer-Centric Strategy Toward Tourist Satisfaction

DOI: 10.54443/ijebas.v1i2.105

\begin{tabular}{|c|c|c|c|c|c|c|c|}
\hline \multirow{3}{*}{$\begin{array}{l}\text { communicati } \\
\text { on } \\
\text { convenience }\end{array}$} & \multicolumn{2}{|c|}{ - } & & \multicolumn{2}{|c|}{ - } & \multicolumn{2}{|c|}{.6} \\
\hline & .014 & 043 & .022 & .330 & 741 & 38 & .567 \\
\hline & & & & & & & \\
\hline & 015 & 060 & 018 & 254 & 800 & 84 & .712 \\
\hline
\end{tabular}

\section{CONCLUSION}

The study aims to find out the relations between the marketing mix and tourists satisfaction in the halal tourism destinations in Aceh. The finding in this study shows that there is three elements a significant positive relationship among the marketing mix and tourist satisfaction. Furthermore the results suggest that the halal tourism destinations in Aceh should consider the importance of the marketing mix, ie: communication while designing their service marketing strategy. The finding of the study are helpful for the halal tourism industry of Aceh in particular and the national tourism industry in general.

\section{ACKNOWLEDGMENT}

The author acknowledge thank you so much especially for LPPM Universitas Malikussaleh as research funders in accordance with the contract letter No. 112/PPK-2/SPK-JL/2021. July 15, 2021. Thanks are also extended to juliana and pendi as student in faculty of economic and business Universitas Malikussaleh for all support in this research.

\section{REFERENCES}

[1] Kemenpar, "Laporan akuntabilitas kinerja kementerian pariwisata" 2018

[2] Kemenpar, "Laporan Akuntabilitas Kinerja Kementerian Pariwisata 2016," pp. 1-255, 2016.

[3] M. Djakfar, Pariwisata Halal perspektif Multidimensi, Edisi 1. Malang, Indonesia: UIN MALIKI PRESS, 2017.

[4] M. Battour and M. N. Ismail, "Halal tourism : Concepts , practises , challenges and future," TMP, pp. 8-12, 2015.

[5] S. Mansouri, "Role of Halal Tourism Ideology in Destination Competitiveness : A Study on Selected Hotels in," 2014.

[6] S. Begum, "Investigating the Impact of Marketing Mix Elements on Tourists 'Satisfaction: An Empirical Study on East Lake," vol. 4, no. 7, 2012.

[7] M. Assistant and F. Sciences, "The Impact of Tourism Marketing Mix Elements on the Satisfaction of Inbound Tourists to Jordan Head of Marketing Department," vol. 6, no. 7, pp. 41-58, 2015.

[8] M. Zaenuri, Perencanaan Strategis Kepariwisataan Daerah Konsep dan Aplikasi, Edisi 1. eGov Publishing, 2012.

[9] Isdarmanto, Dasar-dasar Kepariwisataan dan Pengelolaan Destinasi Pariwisata, Edisi 1. Yogyakarta: Gerbang Media Aksara dan STiPrAM, 2017.

[10] N. L. I Ketut Septia Sapta, Bisnis Pariwisata, Edisis 1. Bali: CV. Noah Atlethia, 2018.

[11] M. Personal and R. Archive, "Munich Personal RePEc Archive Tourism Marketing: A Service Marketing perspective," no. 14031, 2009.

[12] R. I. Mawby, A. S. Tec, C. P. Constantin, I. B. Chit, and B. Tescas, "Addressing the Security Concerns of Locals and Visitors for the Sustainable Development of Tourist Destinations," 2016. 
[13] A. Hasan, "Pengembangan Destinasi Wisata Kawasan Goa Jepang Pundong Bantul," vol. XVI, no. 1, pp. 2619-2642, 2017.

[14] F. adi dan M. K. Hadi, "Vol. 3, No. 1, Januari - Juni 2017," J. MD, vol. 3, no. 1, pp. 99-116, 2017.

[15] Agustinawati, "Pengaruh Servqual Dimension terhadap Kepuasan Wisatawan pada Obyek Wisata Pantai di Kota Lhokseumawe," vol. 7, pp. 1-6, 2018.

[16] Agustinawati and Muhammad Yusuf, "An Investigation of Tourist Satisfaction on Tourism Destination," vol. copyright, no. 2-10, 2019.

[17] P. Jalan and M. Pengembangan, "Pariwisata halal," 2017.

[18] Agustinawati and Cindenia Pusbasari, "Analisis Bauran Pemasaran Destinasi Pariwisata Kota Lhokseumawe," vol. 7, no. September, 2018.

[19] Y. Wardi, "The Influence of Marketing Mix , Islamic Tourism and satisfaction on Visitor Loyalty : a Literature Review," vol. 64, no. 2009, pp. 402-410, 2019.

[20] N. A. Aziz, A. A. M. Ariffin, N. A. Omar, and S. K. Yoon, “An Investigation of International and Domestic Tourists' Satisfactionin Heritage Context: Implications for Destination Marketing," J. Pengur., vol. 33, pp. 61-76, 2011.

[21] F. Abdullah, T. F. Abdullah, and M. F. Abdullah, "Effects of marketing mix on customer satisfaction : empirical study on tourism industry in Malaysia," vol. 2, pp. 357-360, 2016.

[22] H. W. Mimit Primyastanto, Setiawan, "ANALYSIS OF MARKETING MIX AT 'WISATA BAHARI LAMONGAN' LAMONGAN REGENCY, EAST JAVA Mimit Primyastanto $1^{*}$ ), Setiawan 1) and Heru Wiyoto 1) 1)," Econ. Soc. Fish. Mar. J., vol. 04, no. 01, pp. 46-53, 2016.

[23] Agustinawati, "Pengaruh Citra Merek , Kualitas Produk , dan Harga Terhadap Keputusan Membeli," vol. 5, pp. 1-11, 2016.

[24] R. Roostika, "analisis pengaruh bauran pemasaran produk cindera mata terhadap kepuasan wisatawan domestik di yogyakarta," J. Manaj. dan Akunt., vol. 1, no. 3, pp. 104-116, 2012.

[25] M. Personal, R. Archive, and A. Jaelani, "Mp r a,” no. 76237, 2017.

[26] H. Aldebi and N. Aljboory, "The Impact of the Tourism Promotion-Mix Elements on the Foreign Tourists ' Mental Images of the Jordanian Tourist Destinations ( A Field Study)," vol. 11, no. 1, pp. 74-86, 2018.

[27] M. A. Nizar, "Mp r a," no. 65631, 2015.

[28] S. Bagri and D. Kala, "Tourists' satisfaction at Trijuginarayan: An emerging spiritual and adventure tourist destination in Garhwal Himalaya India," Turizam, vol. 19, no. 4, pp. 165-182, 2015.

[29] N. R. Kirom, . S., and I. W. J. Adi Putra, "The Influence of Tourist Attractions Towards the Tourists' Satisfaction,” KnE Soc. Sci., vol. 3, no. 3, p. 270, 2018.

[30] K. Omar and A. R. Mahmmod, "Tourist Satisfaction in Malaysia," vol. 4, no. 5, pp. 221-226, 2013.

[31] Agustinawati, "Analisis Pengaruh Kualitas Pelayanan Terhadap Kepuasan Konsumen Pada Bisnis Kuliner Dengan Pendekatan SERVQUAL," vol. 5, no. September, 2016.

[32] Sugiono, Metode Penelitian Administrasi dilengkapi Metode R\&D. 2009.

[33] 2009 Ghozali, imam, "Aplikasi Analisis Multivariate dengan Program SPSS.".

[34] Suryana, Metodologi penelitian. 2010.

[35] R. A. Purnomo, M. Si, and U. Mahasiswa, Analisis Statistik Ekonomi dan Bisnis Dengan SPSS. 
Volume 1 No 2 (2021)

The Influence Of Customer-Centric Strategy Toward Tourist Satisfaction DOI: 10.54443/ijebas.v1i2.105 